\title{
Compare Laparoscopic and Open Appendectomy in Terms of Surgical Site Infection
}

\author{
MUHAMMAD YOUSAF ${ }^{1}$, SHAHID KHAN AFRIDI ${ }^{2}$, GUL SHARIF ${ }^{3}$, WASIM AHMAD ${ }^{4}$, SHOAIB MUHAMMAD ${ }^{5}$, TANVEER \\ SADIQ $\mathrm{CH}^{6}$ \\ ${ }^{1}$ Senior Registrar General Surgery, Northwest Teaching Hospital Hayatabad, Peshawar \\ ${ }^{2}$ Senior Registrar General Surgery, Muhammad Teaching Hospital, Peshawar \\ ${ }^{3}$ Assistant Professor General Surgery, Lady Reading hospital Peshawar \\ ${ }^{4}$ Assistant Professor General Surgery, Gomal Medical College, D.I Khan \\ ${ }^{5}$ Senior Registrar General Surgery, Muhammad Teaching hospital, Peshawar \\ ${ }^{6}$ Associate Professor General Surgery Mohtarma Benazir Bhutto Shaheed Medical College, Mirpur Azad Kashmir \\ Corresponding author: Dr Gul Sharif, Email: gulafridi1@yahoo.com, Cell No: +92 3005959004
}

\begin{abstract}
Aim: The aim of this study is to compare the outcomes between laparoscopic and open appendectomy in terms of surgical site infection.

Study Design: Prospective/ Observational

Place \& Duration: Department of Surgery, Lady Reading Hospital, Peshawar for duration of six months from January 2021 to June 2021.

Methods: In this study 200 patients of both genders with ages $>10$ years presented with acute appendicitis were included. Patients' demographics including age, sex and body mass index were recorded after written consent. Patients were equally divided into two groups. Group I consist of 100 patients and received laparoscopic appendectomy and Group II with 100 patients received open appendectomy. Outcomes such as surgical site infection, hospital stay and time duration of procedure were examined and compare the results between both groups. Data was analyzed by SPSS 26.0. P-value $<0.05$ was set as significant.

Results: There were 120 (60\%) patients (60 Group I, 60 Group II) were males while 80 (40\%) patients (40 Group I, 40 Group II) were females. Mean age in group I was $27.9+4.45$ years and in group II mean age was $28.5+4.21$ years. Mean BMI in group I was $24.08+8.22 \mathrm{~kg} / \mathrm{m} 2$ and in group II mean BMI was $25.03+6.17 \mathrm{~kg} / \mathrm{m} 2$. There was a significant difference in term of surgery time duration between both groups $42.88+13.75$ minutes Vs $33.35+9.55$ minutes; $P=0.003$. Hospital stay was greater in group II $6.03+3.12$ days as compared to group I 4.07+6.13 days. Post operatively less SSI was found among laparoscopic group 6 (6\%) in which 4\% had superficial SSI and $2 \%$ had deep SSI as compared to group II 12 (12\%) SSI was found among in which $8 \%$ had superficial SSI and $4 \%$ had deep SSI.

Conclusion: We concluded in this study that laparoscopic appendectomy is better in terms of less hospital stay with less surgical site infection as compared to open appendectomy. We found that less operative time was observed in open appendectomy as compared to laparoscopic.
\end{abstract}

Keywords: Appendectomy, Outcomes, Laparoscopic, Open, Acute appendicitis

\section{INTRODUCTION}

6.7 to 8.6 percent of people throughout their lifetime will have appendicitis, the most common cause of acute abdominal pain. It's also the most prevalent emergency in abdominal surgery [3]. Surgical surgery has been the conventional treatment strategy for acute appendicitis since 1889, when Mc Burney first described appendectomy as a therapy for acute appendicitis [4] First described in 1894, the open appendectomy $(\mathrm{OA})$ is performed by an incision in the right lower quadrant. For the past 100 years, it has been the preferred treatment for acute appendicitis due to its efficacy and safety. Appendectomy by laparoscopy was originally documented by Semm in 1983 [5] as a result of the development of endoscopic surgery It's slowly becoming more and more common. As a result of the disagreement over the best way of removing an inflamed appendix, there is no consensus in the literature.

Compared to open appendectomy, endoscopic procedures are said to be less intrusive, less prone to problems, and provide better results [6-8].

There is evidence that low surgical trauma by laparoscopic method resulted in shorter hospital stays, less postoperative discomfort, and speedier return to daily activities in numerous situations linked to gastrointestinal surgery.[9,10] As a result, there have been inconsistent outcomes from various retrospective investigations, randomized controlled trials and meta-analyses comparing laparoscopic vs open appendectomy.[11,12] Some of these studies have showed superior clinical outcomes with the laparoscopic method [13], whereas other studies have indicated minor or no clinical improvements [14] as well as increased surgery expenses. Since open surgery for acute appendicitis has not been shown to be superior to laparoscopic appendectomy [15], we performed this study to examine if there are any benefits to the laparoscopic technique for acute appendicitis patients.

The aim of this study is to compare the outcomes among laparoscopic and open appendectomy in terms of surgical site infection.

\section{MATERIAL AND METHODS}

This prospective study was conducted at department of Surgery, Lady Reading Hospital, Peshawar for duration of six months from January 2021 to June 2021.

The study was consisted of 200 patients. Patients' demographics including age, sex and body mass index 
were recorded after written consent. Histopathology findings of the patients were recorded. Pregnant women, patients with history of abdominal surgery, patients with recurrence and those with no consent were excluded.

Patients were equally divided into two groups. Group I consist of 100 patients and received laparoscopic appendectomy and Group II with 100 patients received open appendectomy. Outcomes such as surgical site infection, hospital stay and time duration of procedure were examined and compare the results between both groups.

Data was analyzed by SPSS 26.0. Chi-square test and student $t$ test was used to compare the findings between both groups. Data was recorded in the form of tables. P-value $<0.05$ was considered as significant.

\section{RESULTS}

There were 120 (60\%) patients (60 Group I, 60 Group II) were male while 80 (40\%) patients (40 Group I, 40 Group II) were females. Mean age in group I was $27.9+4.45$ years and in group IImean age was $28.5+4.21$ years. Mean BMI in group I was $24.08+8.22 \mathrm{~kg} / \mathrm{m} 2$ and in group II mean BMI was $25.03+6.17 \mathrm{~kg} / \mathrm{m} 2$. We found in histopathology results that80 (80\%)patients had inflammation, 6 (6\%)had phlegmonous, 2 (2\%)had gangrenous, 8 (8\%)had perforated and 4(4\%) had normal appendicitis in Group I and in Group II 77(77\%)had inflamed, 6 (6\%)had phlegmonous, 4 (4\%)had gangrenous, 11 (11\%)had perforated and $2(2 \%)$ had normal appendicitis. (Table 1$)$

Table 1: Baseline details of enrolled cases

\begin{tabular}{|l|l|l|l|}
\hline Characteristics & Group I & Group II & Total \\
\hline Mean age (yrs) & $27.9+4.45$ & $28.5+4.21$ & \\
\hline Gender & & & \\
\hline Male & $60(60 \%)$ & $60(60 \%)$ & $120(60 \%)$ \\
\hline Female & $50(40 \%)$ & $50(40 \%)$ & $100(40 \%)$ \\
\hline BMI & $24.08+8.22$ & $25.03+6.17$ & \\
\hline Histopathology & & & \\
\hline Inflamed & $80(80 \%)$ & $77(77 \%)$ & $194(80.8 \%)$ \\
\hline Phlegmonous & $6(6 \%)$ & $6(6 \%)$ & $12(5 \%)$ \\
\hline Gangrenous & $2(2 \%)$ & $4(4 \%)$ & $5(4.2 \%)$ \\
\hline Perforated & $8(8 \%)$ & $11(11 \%)$ & $21(8.75 \%)$ \\
\hline Normal & $4(4 \%)$ & $2(2 \%)$ & $8(3.3 \%)$ \\
\hline
\end{tabular}

There was a significant difference in term of surgery time duration between both groups $42.88+13.75$ minutes $V s$ $33.35+9.55$ minutes; $P=0.003$. Hospital stay was greater in group II $6.03+3.12$ days as compared to group | $4.07+6.13$ days.(Table 2 )

Table No 2. Comparison of surgery time and hospital stay among both groups

\begin{tabular}{|l|l|l|l|}
\hline Characteristics & Group I & Group II & P-value \\
\hline Operative Time (Min) & $42.88+13.75$ & $33.35+9.55$ & 0.003 \\
\hline Hospital Stay & $4.07+6.13$ & $6.03+3.12$ & 0.89 \\
\hline
\end{tabular}

Post operatively less SSI was found among laparoscopic group $6(6 \%)$ in which $4 \%$ had superficial SSI and $2 \%$ had deep SSI as compared to group II 12 (12\%) SSI was found among in which $8 \%$ had superficial SSI and $4 \%$ had deep SSI.(table 3)

Table 3: Comparison of SSI among both groups

\begin{tabular}{|l|l|l|}
\hline \multicolumn{2}{|l|}{ Variables } & \multicolumn{1}{l|}{ Group I } \\
\hline Surgical Site Infection & \multicolumn{2}{l|}{ Group II } \\
\hline Superficial SSI & $4(4 \%)$ & $8(8 \%)$ \\
\hline Deep SSI & $2(2 \%)$ & $4(4 \%)$ \\
\hline Total & $6(6 \%)$ & $12(12 \%)$ \\
\hline
\end{tabular}

\section{DISCUSSION}

Acute appendicitis is the most common intra-abdominal condition requiring emergency surgery. The possibility of appendicitis must be considered in any patient presenting with an acute abdomen, and a certain preoperative diagnosis is still a challenge [16,17]. We presented this study to examine the outcomes of laparoscopic and open appendectomy in term of Surgical site infection. There were 120 (60\%) patients (60 Group I, 60 Group II) were males while 80 (40\%) patients (40 Group I, 40 Group II) were females. Mean age in group I was $27.9+4.45$ years and in group II mean age was $28.5+4.21$ years. Mean BMI in group I was $24.08+8.22 \mathrm{~kg} / \mathrm{m} 2$ and in group II mean BMI was $25.03+6.17 \mathrm{~kg} / \mathrm{m} 2$. Our findings were similar to other previous studies in which majority were male patients 54 $\%$ to $76 \%$ as compared to females and most of the patients were between 20 to 35 years of age $[18,19]$.

We found in histopathology results that 80 (80\%) patients had inflammation, $6(6 \%)$ had phlegmonous, 2 (2\%) had gangrenous, 8 (8\%) had perforated and 4(4\%) had normal appendicitis in Group I and in Group II 77 (77\%) had inflamed, $6(6 \%)$ had phlegmonous, $4(4 \%)$ had gangrenous, 11 (11\%) had perforated and $2(2 \%)$ had normal appendicitis. These results were comparable to some other studies [20].

There was a significant difference in term of surgery time duration between both groups $42.88+13.75$ minutes Vs 33.35+9.55 minutes; $P=0.003$. Different previous studies presented that laparoscopic appendectomy took longer to perform as compared to open appendectomy, these findings were shared by different authors.[21,22]

Hospital stay was greater in group II $6.03+3.12$ days as compared to group I $4.07+6.13$ days. Many different studies presented that laparoscopic technique resulted shorter hospital stay.[23,24] Post operatively less SSI was found among laparoscopic group $6(6 \%)$ in which 4\% had superficial SSI and $2 \%$ had deep SSI as compared to group II 12 (12\%) SSI was found among in which 8\% had superficial SSI and $4 \%$ had deep SSI). These results were similar to many other studies in which significant difference reported in term of SSI between laparoscopic and open technique $[18,25,26]$.

Laparoscopic appendectomy, according to this metaanalysis, has significant advantages over open appendectomy, including lower wound infection rates and fewer postoperative problems. It is therefore worth proposing laparoscopic surgery for individuals with acute appendicitis as an effective and safe therapy option.

\section{CONCLUSION}

We concluded in this study that laparoscopic appendectomy is better in terms of less hospital stay with less surgical site infection as compared to open appendectomy. We found that less operative time was observed in open appendectomy as compared to laparoscopic.

\section{REFERENCES}

1. Addiss DG, Shaffer N, Fowler BS, Tauxe RV (1990) The epidemiology of appendicitis and appendectomy in the United States. Am J Epidemiol 132: 910-925. 
2. Jaschinski T, Mosch C, Eikermann M, Neugebauer EA (2015) Laparoscopic versus open appendectomy in patients with suspected appendicitis: a systematic review of meta-analyses of randomised controlled trials. BMC Gastroenterol 15: 48

3. Casarotto A, Zarantonello FR, Rebonato M (2014) Appendectomy in women. Is the laparoscopic approach always better than the "open" approach in uncomplicated appendicitis? SurgLaparoscEndoscPercutan Tech 24: 406409.

4. McBurney C (1984) The Incision Made in the Abdominal Wall in Cases of Appendicitis, with a Description of a New Method of Operating. Ann Surg 20: 38-43.

5. Semm K (1983) Endoscopic appendectomy. Endoscopy 15: 59-64.

6. Biondi A, Grosso G, Mistretta A, Marventano S, Toscano C, et al. (2013) Laparoscopic vs. open approach for colorectal cancer: evolution over time of minimal invasive surgery. BMC Surg 13: 12.

7. Garbutt JM, Soper NJ, Shannon WD, Botero A, Littenberg B (1999) Meta-analysis of randomized controlled trials comparing laparoscopic and open appendectomy. SurgLaparoscEndosc 1: 17-26.

8. Kurtz RJ, Heimann TM (2001) Comparison of open and laparoscopic treatment of acute appendicitis. Am J Surg. 182: 211-214.

9. Guller U, Hervey S, Purves H, Muhlbaier LH, Peterson ED, Eubanks S, Pietrobon R. Laparoscopic versus open appendectomy: outcomes comparison based on a large administrative database. Ann Surg. 2004;239:43-52.

10. Milewczyk M, Michalik M, Ciesielski M. A prospective, randomized, unicenter study comparing laparoscopic and open treatments of acute appendicitis. SurgEndosc. 2003;17:1023-8.

11. Bresciani C, Perez RO, Habr-Gama A, Jacob CE, Ozaki A, Batagello C, Proscurshim I, Gama-Rodrigues J. Laparoscopic versus standard appendectomy outcomes and cost comparisons in the private sector. J Gastrointest Surg. 2005;9:1174-80

12. Wei B, Qi CL, Chen TF, Zheng ZH, Huang JL, Hu BG, Wei HB. Laparoscopic versus open appendectomy for acute appendicitis: a metaanalysis. SurgEndosc. 2011;25:1199-208

13. Olmi S, Magnone S, Bertolini A, Croce E. Laparoscopic versus open appendectomy in acute appendicitis: a randomized prospective study. SurgEndosc. 2005;19:1193-5.

14. Bresciani C, Perez RO, Habr-Gama A, Jacob CE, Ozaki A, Batagello C, Proscurshim I, Gama-Rodrigues J. Laparoscopic versus standard appendectomy outcomes and cost comparisons in the private sector. J Gastrointest Surg 2005;9:1174-80.
15. Biondi A, Grosso G, Mistretta A, Marventano S, Tropea A, Gruttadauria S, Basile F. Predictors of conversion in laparoscopic-assisted colectomy for colorectal cancer and clinical outcomes. SurgLaparoscEndoscPercutan Tech. 2014;24:21-6.

16. Bhangu A, Søreide K, Di Saverio S, Assarsson JH, Drake FT. Acute appendicitis: modern understanding of pathogenesis, diagnosis, and management. Lancet. 2015;386:1278-87

17. Di Saverio S, Birindelli A, Kelly MD, Catena F, Weber DG, Sartelli M, et al. WSES Jerusalem guidelines for diagnosis and treatment of acute appendicitis. World J Emerg Surg. 2016;11:34

18. Biondi, A., Di Stefano, C., Ferrara, F. et al. Laparoscopic versus open appendectomy: a retrospective cohort study assessing outcomes and cost-effectiveness. World $\mathrm{J}$ EmergSurg 11, 44 (2016).

19. Tiwari, Manish M. MD, PhD, MPH; Reynoso, Jason F. MD Tsang, Albert W. MD; Oleynikov, Dmitry MD, FACS Comparison of Outcomes of Laparoscopic and Open Appendectomy in Management of Uncomplicated and Complicated Appendicitis, Annals of Surgery: December 2011 - Volume 254 - Issue 6 - p 927-932

20. Ignacio RC, Burke R, Spencer D, Bissell C, Dorsainvil C, Lucha PA. Laparoscopic versus open appendectomy: what is the real difference? Results of a prospective randomized double-blinded trial. SurgEndosc. 2004;18:334-7.

21. Wei B, Qi CL, Chen TF, Zheng ZH, Huang JL, Hu BG, Wei HB. Laparoscopic versus open appendectomy for acute appendicitis: a metaanalysis. SurgEndosc. 2011;25:1199_ 208.

22. Sauerland S, Lefering R, Neugebauer EA. Laparoscopic versus open surgery for suspected appendicitis. Cochrane Database Syst Rev. 2010;10:CD001546

23. Shaikh AR, Sangrasi AK, Shaikh GA. Clinical Outcomes of laparoscopic versus open Appendectomy. JSLS. 2009;13:574-80

24. Sauerland S, Lefering R, Neugebauer EA. Laparoscopic versus open surgery for suspected appendicitis. Cochrane Database Syst Rev. 2010;10:CD001546

25. Mantoglu B, Karip B, Mestan M, Iscan Y, Agca B, et al. (2015) Should appendectomy be performed laparoscopically? Clinical prospective randomized trial. Ulus CerrahiDerg 31: 224-228.

26. Zhang H, Gao H, Ma X (2017) Comparison of Short-Term Outcome between Laparoscopic and Open Appendectomy in Adults: A Meta-Analysis of Randomized Controlled Trials. DiagnPathol Open 2: 131. 